\title{
Effect of Photobiomodulation on the Mesenchymal Stem Cells
}

Shin Hyuk Yoo ${ }^{1,2}$

1Department of Otorhinolaryngology, Dankook
University College of Medicine, Cheonan, Korea
${ }^{2}$ Institute of Tissue Regeneration Engineering
(ITREN), Dankook University, Cheonan, Korea

Received June 4, 2020

Accepted July 20, 2020

\section{Correspondence}

Shin Hyuk Yoo

Department of Otorhinolaryngology, Dankook University College of Medicine, 119 Dandae-ro, Dongnam-gu, Cheonan 31116, Korea

Tel.: +82-41-550-3933

Fax: +82-41-556-1090

E-mail: shyoomddamail.com

(C) Korean Society for Laser Medicine and Surgery

(c) This is an open access article distributed under the terms of the Creative Commons Attribution NonCommercial License (http://creativecommons.org/ licenses/by-nc/4.0) which permits unrestricted noncommercial use, distribution, and reproduction in any medium, provided the original work is properly cited.
Photobiomodulation forms the basis of photomedicine and is defined as the effect of coherent or non-coherent light sources, such as low-level lasers and light-emitting diodes, on cells and tissues. This treatment technique affects cell functions, proliferation, and migration, and plays an important role in tissue regeneration. Mesenchymal stem cells (MSCs) are known to be beneficial for tissue regeneration, and the combination of stem cell therapy and laser therapy appears to positively affect treatment outcomes. In general, a low-power laser has a positive effect on MSCs, thereby facilitating improvements in different disease models. This study elucidates the mechanisms and effects of low-power laser irradiation on the proliferation, migration, and differentiation of various MSCs that have been examined in different studies.

\section{Key words}

Photobiomodulation; Mesenchymal stem cell; Laser; Low-level lasers 


\section{INTRODUCTION}

Stem cells are unspecialized, immature cells with selfrenewal features that provide a cell source for tissue regeneration and replacement of damaged organs. 'Differentiation is a critical cellular stage for these cells that allows them to provide specialized cells to form different tissues or organs. Growth factors, extracellular matrices, and cell types are useful in tissue engineering because they increase stem cell differentiation to other cells. ${ }^{2}$

Mesenchymal stem cells (MSCs) are mesenchymal stromal cells, regardless of their tissue origin; they were originally found in bone marrow. However, MSCs can be harvested from other adult tissues. ${ }^{3}$ These pluripotent cells can differentiate into osteocytes, chondrocytes, and adipocytes. ${ }^{4}$ While MSCs can be isolated from many organs, the umbilical cord, umbilical cord blood, and amniotic fluid are the major perinatal MSC sources. Many postnatal organs can be sources of MSCs, including the skin, adipose tissue, blood vessels, and dental pulp. ${ }^{5}$

Photobiomodulation (PBM) can be used to promote cell differentiation and expansion. Furthermore, lasers were almost immediately used in medical applications after their invention. Photomedicine is the study and application of light in health care and disease treatment ${ }^{6}$ and has been used in dermatology, surgery, intervention radiology, ophthalmology, cardiology, and oncology. PBM therapy promotes cell growth, regeneration, and healing of tissue by means of light sources such as light emitting diodes (LEDs) and low-level lasers (LLL), or other light sources that emit light in the visible red to near-infrared (NIR) range. ${ }^{7}$

Several basic in vitro and in vivo studies have examined the effects of PBM, which can be either inhibitory or stimulatory for pain control and regarded as antiinflammatory effects, or considered to be metabolic or immunological. ${ }^{8}$ PBM affects the activity of endogenous enzyme photoacceptors for the initiation of cell signaling pathways. This alters cell and tissue metabolism and cell proliferation. However, the mechanism of the therapeutic laser effect remains poorly understood with respect to its cellular and molecular effects. ${ }^{9}$ The present paper aims to review the effects of low-power laser irradiation on the proliferation, migration, and differentiation of different types of MSCs that have been examined in previous studies reported in the literature.

\section{MOLECULAR MECHANISMS OF PBM}

\section{TPKR/Ras/Raf/MEK/ERK/Mnk1/elF4E/CyclinD1 pathway}

Several studies have shown that low-power lasers can induce tyrosine-protein kinase receptor (TPKR) such as c-MET that can activate the mitogen-activated protein kinases (MAPK), thereby inducing cell proliferation. This was originally called ERK or extracellular signal-regulated kinase signaling pathway. Eukaryotic initiation factor $4 \mathrm{E}$ (elF4E) is a major regulator of cap-dependent mRNA that responds to various stimuli such as hormones, growth factors, and mitogens. Low-level laser irradiation can also phosphorylate protein heat and acid-stable (PHAS-1) and upregulate the expression of elF4E and CyclinD, and also increase the proliferation of cells. ${ }^{10,11}$

\section{TPKR/PI3K/Akt/mTOR/elF4E pathway}

Phosphoinositide 3-kinase (PI3K) phosphorylation is the most important downstream TPKR pathway. LLL can increase the phosphorylation of Akt and the PI3K pathway, inducing the phosphorylation of PHAS-1 through the phosphorylation of mammalian target of rapamycin (mTOR). ${ }^{12,13}$ It activates proliferation and cell migration through elF4E phosphorylation.

\section{TPKR/PLC-gamma/PKC pathway}

The activation of phospholipase C (PLC) can catalyze phospholipids, thereby increasing the concentration of diacylglycerol (DAG) and inositol trisphosphate (IP3). ${ }^{14}$ IP3 can increase the levels of calcium from the endoplasmic reticulum, activating protein kinase C (PKC). PKC is effective in cell proliferation, differentiation, and apoptosis. The application of LLL increased the calcium level, thereby promoting cell proliferation.

\section{PI3K/Akt/eNOS pathway}

Nitric oxide (NO) can promote angiogenesis and the endothelial nitric oxide synthase (eNOS) signaling pathway can result in a low level of NO. The application of a lowpower laser $(632.5 \mathrm{~nm})$ can enhance eNOS expression in endothelial cells, promoting proliferation and migration of endothelial cell migration, which is important in angiogenesis. $^{7,15}$

\section{ATP/CAMP/JNK/AP-1 pathway}

The PBM through LLL can result in an increase in cyclic adenosine monophosphate (CAMP) and consequently cJun N-terminal kinase (JNK) phosphorylation, increasing activator protein 1 (AP-1). AP-1 enhances the expression 
of genes involved in proliferation, survival, and angiogenesis. $^{16,17}$

\section{MSCS STUDIED TO DATE}

\section{MSCs derived from dental pulp}

Dental pulp stem cells have fibroblastic morphology and can differentiate into different types of cells. ${ }^{18}$ Increased osteogenic differentiation in dental pulp stem cells due to LLL irradiation was demonstrated. ${ }^{18}$ In another study, LLL irradiation of cells has been shown to significantly increase osteogenic and odontogenic differentiation as well as the self-renewal and survival of pulpal stem cells. ${ }^{19}$

\section{Adipose MSCs}

It was shown that the use of a low-power laser $1660 \mathrm{~nm}$ $\pm 20 \mathrm{~nm}, 6 \mathrm{~J} / \mathrm{cm}^{2}, 10 \mathrm{mV} / \mathrm{cm}^{2}$ ) can increase the levels of angiogenic factors in adipose MSCs, and after transplantation, could differentiate endothelial cells and improve function. ${ }^{20}$ This study showed that apoptosis was reduced in adipose MSCs after treatment with a low-power laser. After identification of CD31, CD34, von Willebrand Factor (vWF), and kD markers by immunofluorescence, the differentiation of the MSCs into the endothelial cells was confirmed. ${ }^{21,22}$ LLL irradiation (wavelength: $660 \mathrm{~nm}+20$ $\mathrm{nm}, 220 \mathrm{~V}+22 \mathrm{~V}, 50 \mathrm{~Hz}$ ) can increase cell migration by increasing the levels of focal adhesion kinase (FAK) that regulates cell adhesion and migration signals in cells. The studies also showed that the proliferation and viability of MSCs increased. In one study, it was found that the growth factors of the hepatocyte growth factor (HGF) and platelet-derived growth factor (PDGF) were also elevated. ${ }^{17}$ The use of a low-power laser $\left(808 \mathrm{~nm}, 3 \mathrm{~J} / \mathrm{cm}^{2}\right.$, $200 \mathrm{mV}, 0.2 \mathrm{~W} / \mathrm{cm}^{2}$ ) for seven days and $5 \mathrm{~min}$ increased the proliferation and viability of the cells. ${ }^{23}$ The effect of a low-power laser $\left(660 \mathrm{~nm}\right.$ and $\left.0.5,1 \mathrm{~J} / \mathrm{cm}^{2}\right)$ on adipose and bone marrow-derived MSCs was found to be dosedependent and led to increased cell growth and proliferation without any nuclear changes. ${ }^{24}$ In another study, low-power lasers $\left(660 \mathrm{~nm}, 550 \mathrm{~mW} / \mathrm{cm}^{2}\right.$ ) accelerated ischemic limb function by accelerating endothelial cell differentiation and secreting growth factors (vascular endothelial growth factor (VEGF), HGF, and fibroblast growth factor (FGF-RRB -). ${ }^{25}$

It was reported that the toxic effects of doxorubicin on adipose MSCs can be reduced by low-power laser irradiation (wavelength $660 \mathrm{~nm}$, output power $30 \mathrm{~mW}$, a laser beam of $0.028 \mathrm{~cm}^{2}$, and irradiation of $1.07 \mathrm{~mW} / \mathrm{cm}^{2}$ ). A low-power laser with these characteristics increases the viability of MSCs and inhibits apoptosis and oxidative stress in the MSCs that are treated with doxorubicin. ${ }^{26}$ Another study found that a gallium-aluminum-arsenide (GaAlAs) laser (650 nm, $4 \mathrm{~J} / \mathrm{cm}^{2}$ ) improved the repair in a mouse model of skin aging by increasing the proliferation, differentiation, and secretion of the growth factor of the MSCs. Furthermore, the expression of mesenchymal surface markers increased. ${ }^{27}$

\section{Bone marrow MSCs}

A study showed that a low-power laser $\left(2,4 \mathrm{~J} / \mathrm{cm}^{2}\right)$ significantly increased the proliferation of bone marrow MSCs and differentiated them into osteocytes. ${ }^{28}$ Moreover, this study showed that laser irradiation $\left(16 \mathrm{~J} / \mathrm{cm}^{2}\right)$ significantly suppressed proliferation and differentiation into the bones. Low-power lasers at the power of 4, 8, and $16 \mathrm{~J} / \mathrm{cm}^{2}$ also inhibited the expression of tumor necrosis factor- $\alpha$ (TNF- $\alpha){ }^{29}$ Another study showed that irradiation of bone marrow MSCs by a low-power laser $(20 \mathrm{~mJ} /$ $\mathrm{cm}^{2}$ ) differentiated them into neuronal cells. An increased expression of beta-tubulin II protein was also found in this study. ${ }^{30}$

It was shown that LLL irradiation applied to the osteoporosis MSCs from ovariectomized mice significantly increased the optical density and cell viability compared to the control group. ${ }^{31}$ Another study showed that the effects of a low-power laser strongly depended on the wavelength, the number of laser therapy sessions, the state of MSC physiology, and the type of laser. ${ }^{32}$

Many studies have shown that the use of MSCs in the oral maxillofacial area is highly promising. It was shown that the use of a low-power laser $\left(808 \mathrm{~nm}, 64 \mathrm{~J} / \mathrm{cm}^{2}\right)$ increased the expression of important markers for osteoblast differentiation, such as Runt-related transcription factor 2 (RUNX2), alkaline phosphatase (ALP), and osteoblast-specific transcription factor, osterix (OSX). In this study, the reduction of pro-inflammatory factors (IL-6 and $\mathrm{IL}-17$ ) and an increase in anti-inflammatory cytokines (IL10 and IL-1) were also observed. ${ }^{33}$ In another study, lowpower lasers ( $15 \mathrm{~Hz}, 150 \mathrm{~mJ}, 2.25 \mathrm{~W})$ were demonstrated to proliferate and differentiate bone marrow MSCs into osteoblasts in 3-dimensional collagen scaffolds that can be used in the treatment of periodontal diseases. ${ }^{34}$

The use of stem cells has been studied as a novel therapeutic approach for the treatment of cardiovascular disease that is one of the leading causes of death worldwide. It was shown that the use of an $810 \mathrm{~nm}$ low-power laser significantly reduced the size of the myocardial infarction and significantly increased cell proliferation. ${ }^{35} \mathrm{Hou}$ et al. found that the use of a low-power laser $\left(0.5 \mathrm{~J} / \mathrm{cm}^{2}\right)$ 
promoted the proliferation of MSCs and their myogenic differentiation, while facilitating the secretion of VEGF and nerve growth factor (NGF). ${ }^{36}$ In another study, LLL 1660 $\mathrm{nm}, 5 \mathrm{~mW}, 6,10,12 \mathrm{~J} / \mathrm{cm}^{2}$ ) was also shown to significantly increase the proliferation and viability of the bone marrow MSCs in the reactive oxygen species (ROS). ${ }^{37}$

\section{Blood MSCs}

MSCs can also be used to repair damaged tendons. A study showed that human blood MSCs can be differentiated into tenocytes by LLL. The use of growth factors (epidermal growth factor-2 (EGF2), transforming growth factor beta-3 (TGFB3), insulin-like growth factor-1 (IGF-1), and basic fibroblast growth factor-2 (bFGF2)) with LLL led to the expression of the most important tenogenic genes such as early growth response protein 1 (EGR1), tenascin c (TNC), and decorin (DCN). ${ }^{38}$

\section{EFFECT OF DIFFERENT WAVELENGTHS AND LIGHT DOSES ON PBM}

A biphasic response to $L L L$ treatment has been demonstrated in several studies. ${ }^{39,40}$ The Arndt-Schulz Law has been frequently used as a suitable model to describe the dose-dependent effects of $L L L$ therapy. ${ }^{41-43} \mathrm{~A}$ "biphasic" curve can be used to illustrate the expected dose response to light at a subcellular, cellular, tissue, or clinical level. If insufficient energy is applied, there will be no response because the minimum threshold has not been met. If more energy is applied, the threshold is crossed and biostimulation is achieved; however, when too much energy is applied, the stimulation disappears and is replaced by disinhibition instead.

One study examined the effects of PBM treatment on dental derived MSCs, and the obtained results appeared to follow the Arndt-Schulz law. ${ }^{44}$ When the lowest $(0.05$
$\mathrm{J} / \mathrm{cm}^{2}$ ) and the highest $\left(42 \mathrm{~J} / \mathrm{cm}^{2}\right.$ ) energy densities were applied, no effects were observed. A therapeutic window was observed in the intermediate energy density range $\left(1-4 \mathrm{~J} / \mathrm{cm}^{2}\right)$. In this range of energy densities, positive effects of PBM therapy were observed, as demonstrated in literature for other cell types. ${ }^{45-47}$

Since wavelength affects tissue penetration, shorter wavelengths $(600-700 \mathrm{~nm})$ are considered to be optimal for the treatment of superficial tissue, and longer wavelengths $(780$ to $950 \mathrm{~nm}$ ) are preferred for the treatment of deeper tissues. Wavelengths in the $700-770 \mathrm{~nm}$ range showed no significant activity. ${ }^{48}$ Wu et al. used a $730 \mathrm{~nm}$ laser on mice with traumatic brain injuries and found it to be ineffective, while irradiation treatments using 660 and $810 \mathrm{~nm}$ lasers were effective. ${ }^{49}$ For wound healing in mice, Gupta et al. found that treatments with 660 - and $810 \mathrm{~nm}$ lasers were effective, while the treatment with a $730 \mathrm{~nm}$ laser was not effective. ${ }^{50}$

The combination of two wavelengths provides an additional effect of the PBM. Comparing irradiation at 830 and $685 \mathrm{~nm}$, Mendez and colleagues found that irradiation at $830 \mathrm{~nm}$ led to better results. ${ }^{51}$ A recent study showed that PBM with irradiation at both 630 and $810 \mathrm{~nm}$ significantly stimulated cell viability and decreased apoptosis of human bone marrow MSCs in vitro. ${ }^{52}$

\section{CONCLUSIONS}

Table 1 summarizes the results of some studies on the effects of LLL on stem cells. Previous studies have shown that PBM increases the differentiation, proliferation, and migration of MSCs. These results depend on factors such as energy density, power output, frequency of radiation, and the types of light source, cell, or medium culture. To obtain favorable results, standardization of parameters in PBM experiments is required. Since PBM has positive

Table 1. Results of researches on the effects of photobiomodulation on the stem cells

\begin{tabular}{|c|c|c|c|c|c|c|c|}
\hline Type of cells & $\begin{array}{l}\text { Wavelength } \\
\qquad(\mathrm{nm})\end{array}$ & $\begin{array}{l}\text { Output power } \\
\text { (mW) }\end{array}$ & $\begin{array}{l}\text { Laser beam } \\
\qquad\left(\mathrm{cm}^{2}\right)\end{array}$ & $\begin{array}{l}\text { Energy density } \\
\qquad\left(\mathrm{J} / \mathrm{cm}^{2}\right)\end{array}$ & $\begin{array}{l}\text { Irradiation } \\
\left(\mathrm{mW} / \mathrm{cm}^{2}\right)\end{array}$ & $\begin{array}{c}\text { Total } \\
\text { treatment }\end{array}$ & Reference \\
\hline Dental MSC & 660 & 20 & 0.028 & 3,5 & 0.71 & $4 \mathrm{~s}, 7 \mathrm{~s}$ & Diniz et al. ${ }^{19}$ \\
\hline \multirow{5}{*}{ Adipose MSC } & 660 & 30 & 0.028 & 0.2 & 1.07 & & De Lima et al. ${ }^{26}$ \\
\hline & $660 \pm 20$ & - & - & 6 & 10 & $10 \mathrm{~min}$ & Park et al. ${ }^{21}$ \\
\hline & $660 \pm 20$ & 3 and 4.5 & - & - & - & $1 \mathrm{~h}$ & Yin et al. ${ }^{17}$ \\
\hline & 808 & 200 & - & 3 & 0.2 & 7 days (5 min) & Nurković et al. ${ }^{23}$ \\
\hline & 636 & 85 & 9.08 & 5 & 9.3 & $9 \min 10 s$ & Mvula et al. ${ }^{39}$ \\
\hline \multirow[t]{2}{*}{ BM MSC } & - & 0.25 & & $2,4,16$ & & $20 \mathrm{~s}$ & Wang et al. ${ }^{29}$ \\
\hline & 632.8 & 3 & 1.56 & 1.2 & & $378 \mathrm{~s}$ & Fallahnezhad et al. ${ }^{32}$ \\
\hline Blood MSC & 660 & - & - & 5 & - & $2 \min$ & Gomiero et al. ${ }^{38}$ \\
\hline
\end{tabular}

MSC, mesenchymal stem cell; BM, bone marrow. 
effects on biostimulation, proliferation, and differentiation of MSCs, it can be a powerful tool in regenerative treatments.

\section{CONFLICTS OF INTEREST}

The authors declare no potential conflicts of interest with respect to the research, authorship, and/or publication of this article.

\section{FINANCIAL DISCLOSURE}

The author has no financial interests related to the content of this article. No outside funding was received.

\section{REFERENCES}

1. Otsu K, Kumakami-Sakano M, Fujiwara N, Kikuchi K, Keller L, Lesot $H$, et al. Stem cell sources for tooth regeneration: current status and future prospects. Front Physiol 2014;5:36.

2. Egusa H, Sonoyama W, Nishimura M, Atsuta I, Akiyama K. Stem cells in dentistry--part I: stem cell sources. J Prosthodont Res 2012;56:151-65.

3. Friedenstein AJ, Chailakhjan RK, Lalykina KS. The development of fibroblast colonies in monolayer cultures of guinea-pig bone marrow and spleen cells. Cell Tissue Kinet 1970;3:393403.

4. Pittenger MF, Mackay AM, Beck SC, Jaiswal RK, Douglas R, Mosca JD, et al. Multilineage potential of adult human mesenchymal stem cells. Science 1999;284:143-7.

5. Ishizaka R, lohara K, Murakami M, Fukuta O, Nakashima M. Regeneration of dental pulp following pulpectomy by fractionated stem/progenitor cells from bone marrow and adipose tissue. Biomaterials 2012;33:2109-18.

6. Moore KC. Photomedicine: the early years. Photomed Laser Surg 2013;31:563-4.

7. Szymczyszyn A, Doroszko A, Szahidewicz-Krupska E, Rola P, Gutherc R, Jasiczek J, et al. Effect of the transdermal lowlevel laser therapy on endothelial function. Lasers Med Sci 2016;31:1301-7.

8. Roelandts R. The history of phototherapy: something new under the sun? J Am Acad Dermatol 2002;46:926-30.

9. Poyton RO, Ball KA. Therapeutic photobiomodulation: nitric oxide and a novel function of mitochondrial cytochrome c oxidase. Discov Med 2011;11:154-9.

10. Gao X, Xing D. Molecular mechanisms of cell proliferation induced by low power laser irradiation. J Biomed Sci 2009;16:4.

11. Ganjali M, Seifalian AM, Mozafari M. Effect of laser irradiation on cell cycle and mitosis. J Lasers Med Sci 2018;9:249-53.

12. Wu YH, Wang J, Gong DX, Gu HY, Hu SS, Zhang H. Effects of low-level laser irradiation on mesenchymal stem cell proliferation: a microarray analysis. Lasers Med Sci 2012;27:509-19.

13. Cianciulli A, Calvello R, Porro C, Trotta T, Salvatore R, Panaro MA. PI3k/Akt signalling pathway plays a crucial role in the antiinflammatory effects of curcumin in LPS-activated microglia. Int Immunopharmacol 2016;36:282-90.

14. Araújo TG, Oliveira AG, Franchi Teixeira AR. Low-power laser irradiation (LPLI): a clinical point of view on a promising strategy to improve liver regeneration. J Lasers Med Sci 2018;9:2237.

15. Chen $\mathrm{CH}$, Hung HS, Hsu SH. Low-energy laser irradiation increases endothelial cell proliferation, migration, and eNOS gene expression possibly via PI3K signal pathway. Lasers Surg Med 2008;40:46-54.

16. Zhang J, Xing D, Gao X. Low-power laser irradiation activates Src tyrosine kinase through reactive oxygen species-mediated signaling pathway. J Cell Physiol 2008;217:518-28.

17. Yin K, Zhu R, Wang S, Zhao RC. Low-level laser effect on proliferation, migration, and antiapoptosis of mesenchymal stem cells. Stem Cells Dev 2017;26:762-75.

18. Pinheiro CCG, de Pinho MC, Aranha AC, Fregnani E, Bueno DF. Low power laser therapy: a strategy to promote the osteogenic differentiation of deciduous dental pulp stem cells from cleft lip and palate patients. Tissue Eng Part A 2018;24:569-75.

19. Diniz IMA, Carreira ACO, Sipert CR, Uehara CM, Moreira MSN, Freire $L$, et al. Photobiomodulation of mesenchymal stem cells encapsulated in an injectable rhBMP4-loaded hydrogel directs hard tissue bioengineering. J Cell Physiol 2018;233:4907-18.

20. Park IS, Chung PS, Ahn JC, Leproux A. Human adipose-derived stem cell spheroid treated with photobiomodulation irradiation accelerates tissue regeneration in mouse model of skin flap ischemia. Lasers Med Sci 2017;32:1737-46.

21. Park IS, Chung PS, Ahn JC. Angiogenic synergistic effect of adipose-derived stromal cell spheroids with low-level light therapy in a model of acute skin flap ischemia. Cells Tissues Organs 2016;202:307-18.

22. Park IS, Chung PS, Ahn JC. Enhancement of ischemic wound healing by spheroid grafting of human adipose-derived stem cells treated with low-level light irradiation. PLoS One 2015;10:e0122776.

23. Nurković J, Zaletel I, Nurković S, Hajrović Š, Mustafić F, Isma J, et al. Combined effects of electromagnetic field and low-level laser increase proliferation and alter the morphology of human adipose tissue-derived mesenchymal stem cells. Lasers Med Sci 2017;32:151-60

24. Barboza CA, Ginani F, Soares DM, Henriques AC, Freitas Rde A. Low-level laser irradiation induces in vitro proliferation of mesenchymal stem cells. Einstein (Sao Paulo) 2014;12:75-81.

25. Park IS, Chung PS, Ahn JC. Enhanced angiogenic effect of adipose-derived stromal cell spheroid with low-level light therapy 
in hind limb ischemia mice. Biomaterials 2014;35:9280-9.

26. de Lima RDN, Vieira SS, Antonio EL, Camillo de Carvalho PT, de Paula Vieira R, Mansano BSDM, et al. Low-level laser therapy alleviates the deleterious effect of doxorubicin on rat adipose tissue-derived mesenchymal stem cells. J Photochem Photobiol B 2019;196:111512.

27. Liao X, Li SH, Xie GH, Xie S, Xiao LL, Song JX, et al. Preconditioning with low-level laser irradiation enhances the therapeutic potential of human adipose-derived stem cells in a mouse model of photoaged skin. Photochem Photobiol 2018;94:78090.

28. Sefati N, Abbaszadeh HA, Fadaei Fathabady F, Abdollahifar MA, Khoramgah MS, Darabi S, et al. The combined effects of mesenchymal stem cell conditioned media and low-level laser on stereological and biomechanical parameter in hypothyroidism rat model. J Lasers Med Sci 2018;9:243-48.

29. Wang L, Wu F, Liu C, Song Y, Guo J, Yang Y, et al. Low-level laser irradiation modulates the proliferation and the osteogenic differentiation of bone marrow mesenchymal stem cells under healthy and inflammatory condition. Lasers Med Sci 2019;34:169-78.

30. Ferreira-Silva V, Primo FL, Baqui MMA, Magalhães DAR, Orellana MD, Castilho-Fernandes A, et al. Beneficial role of low-intensity laser irradiation on neural $\beta$-tubulin III protein expression in human bone marrow multipotent mesenchymal stromal cells. Stem Cell Rev Rep 2018;14:585-98.

31. AlGhamdi KM, Kumar A, Moussa NA. Low-level laser therapy: a useful technique for enhancing the proliferation of various cultured cells. Lasers Med Sci 2012;27:237-49.

32. Fallahnezhad S, Piryaei A, Tabeie F, Nazarian $H$, Darbandi $H$, Amini A, et al. Low-level laser therapy with helium-neon laser improved viability of osteoporotic bone marrow-derived mesenchymal stem cells from ovariectomy-induced osteoporotic rats. J Biomed Opt 2016;21:98002.

33. Amaroli A, Agas D, Laus F, Cuteri V, Hanna R, Sabbieti MG, et al. The effects of photobiomodulation of $808 \mathrm{~nm}$ diode laser therapy at higher fluence on the in vitro osteogenic differentiation of bone marrow stromal cells. Front Physiol 2018;9:123.

34. Leonida A, Paiusco A, Rossi G, Carini F, Baldoni M, Caccianiga G. Effects of low-level laser irradiation on proliferation and osteoblastic differentiation of human mesenchymal stem cells seeded on a three-dimensional biomatrix: in vitro pilot study. Lasers Med Sci 2013;28:125-32.

35. Tuby H, Maltz L, Oron U. Low-level laser irradiation (LLLI) promotes proliferation of mesenchymal and cardiac stem cells in culture. Lasers Surg Med 2007;39:373-8.

36. Hou JF, Zhang H, Yuan X, Li J, Wei YJ, Hu SS. In vitro effects of low-level laser irradiation for bone marrow mesenchymal stem cells: proliferation, growth factors secretion and myogenic differentiation. Lasers Surg Med 2008;40:726-33.
37. Cavalcanti MF, Maria DA, de Isla N, Leal-Junior EC, Joensen J, Bjordal JM, et al. Evaluation of the proliferative effects induced by low-level laser therapy in bone marrow stem cell culture. Photomed Laser Surg 2015;33:610-6.

38. Gomiero C, Bertolutti G, Martinello T, Van Bruaene N, Broeckx SY, Patruno M, et al. Tenogenic induction of equine mesenchymal stem cells by means of growth factors and low-level laser technology. Vet Res Commun 2016;40:39-48.

39. Lanzafame RJ, Stadler I, Kurtz AF, Connelly R, Peter TA Sr, Brondon $\mathrm{P}$, et al. Reciprocity of exposure time and irradiance on energy density during photoradiation on wound healing in a murine pressure ulcer model. Lasers Surg Med 2007;39:53442.

40. Oron U, Yaakobi T, Oron A, Hayam G, Gepstein L, Rubin O, et al. Attenuation of infarct size in rats and dogs after myocardial infarction by low-energy laser irradiation. Lasers Surg Med 2001;28:204-11.

41. Chow RT, Heller GZ, Barnsley L. The effect of $300 \mathrm{~mW}, 830$ $\mathrm{nm}$ laser on chronic neck pain: a double-blind, randomized, placebo-controlled study. Pain 2006;124:201-10.

42. Hawkins D, Abrahamse H. Effect of multiple exposures of lowlevel laser therapy on the cellular responses of wounded human skin fibroblasts. Photomed Laser Surg 2006;24:705-14.

43. Lubart R, Lavi R, Friedmann H, Rochkind S. Photochemistry and photobiology of light absorption by living cells. Photomed Laser Surg 2006;24:179-85.

44. Pereira LO, Longo JP, Azevedo RB. Laser irradiation did not increase the proliferation or the differentiation of stem cells from normal and inflamed dental pulp. Arch Oral Biol 2012;57:107985.

45. Pereira AN, Eduardo Cde P, Matson E, Marques MM. Effect of low-power laser irradiation on cell growth and procollagen synthesis of cultured fibroblasts. Lasers Surg Med 2002;31:2637.

46. Marques MM, Pereira AN, Fujihara NA, Nogueira FN, Eduardo CP. Effect of low-power laser irradiation on protein synthesis and ultrastructure of human gingival fibroblasts. Lasers Surg Med 2004;34:260-5.

47. Eduardo FP, Mehnert DU, Monezi TA, Zezell DM, Schubert MM, Eduardo CP, et al. Cultured epithelial cells response to phototherapy with low intensity laser. Lasers Surg Med 2007;39:36572.

48. Karu TI. Multiple roles of cytochrome c oxidase in mammalian cells under action of red and IR-A radiation. IUBMB Life 2010;62:607-10.

49. Wu Q, Xuan W, Ando T, Xu T, Huang L, Huang YY, et al. Low-level laser therapy for closed-head traumatic brain injury in mice: effect of different wavelengths. Lasers Surg Med 2012;44:21826.

50. Gupta A, Dai T, Hamblin MR. Effect of red and near-infrared 
wavelengths on low-level laser (light) therapy-induced healing of partial-thickness dermal abrasion in mice. Lasers Med Sci 2014;29:257-65

51. Vera Mendez TMT, Pinheiro ALB, Pacheco MTT, Ramalho LMP, do Nascimento PM. Assessment of the influence of the dose and wavelength of LLLT on the repair of cutaneous wounds. San Jose: ProcSPIE; 2003. p.137-43.

52. Zare F, Moradi A, Fallahnezhad S, Ghoreishi SK, Amini A, Chien S, et al. Photobiomodulation with 630 plus $810 \mathrm{~nm}$ wavelengths induce more in vitro cell viability of human adipose stem cells than human bone marrow-derived stem cells. J Photochem Photobiol B 2019;201:111658.

How to cite this article: Yoo SH. Effect of photobiomodulation on the mesenchymal stem cells. Med Lasers 2020;9:119-125. https://doi.org/10.25289/ML.2020.9.2.119 